Francesco Amenta

Roberto Avola

Elena Bronzetti

Laura Felici

Giovanni Germanà

Fiorenzo Mignini

Alberto Ricci

Maurizio Sabbatini

Received: 18 January 2000

Accepted in revised form: 22 February 2000

F. Amenta $(\varangle)$ • F. Mignini • M. Sabbatini Section of Human Anatomy,

Department of Pharmacological Sciences and Experimental Medicine,

University of Camerino,

Via Scalzino 3, I-62032 Camerino, Italy

e-mail: amenta@cambio.unicam.it

Tel.: +39-0737-403311

Fax: +39-0737-630618

R. Avola

Section of Biochemistry,

Department of Chemistry,

University of Catania, Catania, Italy

E. Bronzetti • L. Felici • A. Ricci

Department of Cardiovascular and

Respiratory Sciences,

University La Sapienza, Rome, Italy

G. Germanà

Institute of Domestic Animal Anatomy, with Histology and Embriology,

University of Messina, Messina, Italy

\section{Dopamine D1-D5 receptor protein immunohistochemistry in dog pial arteries}

\begin{abstract}
dopamine D5 receptor protein immunostaining was observed in smooth muscle of the tunica media. These findings indicate that dog pial arteries express dopamine D1-like (D1 and D5) and D2-like (D2 and D4) receptor subtypes and display, respectively, a muscular (post-junctional) and probably prejunctional localization. These results, the first analysis of dopamine D1-D5 receptor subtype distribution in the cerebrovascular tree, suggest that dopamine is involved in the regulation of cerebral circulation. These findings may help evaluate the role of cerebrovascular dopaminergic mechanisms in the pathogenesis of migraine.
\end{abstract}

Key words Dopamine receptors • Pial arteries - Immunohistochemistry • Prejunctional receptors $\cdot$ Post-junctional receptors

\section{Introduction}

Several studies have suggested a role of dopamine in the pathophysiology of migraine [1]. Functional experiments have shown that dopamine is involved in the control of cerebral circulation. Dopamine after blockade of alpha- or beta-adrenoceptors induces relaxation of the smooth muscle of cerebral arteries. These effects are mimicked by dopamine receptor agonists and blocked by dopamine receptor antagonists [2-4]. On the other hand, dopamine induces vasodilatation of pial arteries through an interaction 
with alpha2 adrenoceptors and dopamine D1 and D2 receptors [5]. In vivo investigations have demonstrated cerebral vasodilatation subsequent to dopamine administration [6] or after microapplication or perivascular microinjection of dopamine to pial arteries or subarachnoid membrane [6-8]. These effects were likely mediated through the interaction of dopamine with specific dopamine receptors since they were abolished by dopamine receptor antagonists [9]. More recent in vivo studies have also demonstrated an increase of regional cerebral blood flow by the dopamine receptor agonist apomorphine [10] and by the mixed D1/D2 dopamine receptor agonist Z1046 [11].

Vascular actions of dopamine are mediated primarily through its interaction with specific receptors located in the cardiovascular system. The first studies on the classification of peripheral dopamine receptors identified two receptor subtypes, defined $\mathrm{DA}_{1}$ and $\mathrm{DA}_{2}$ receptors and considered similar but not identical to the homologous brain $\mathrm{D}_{1}$ and $\mathrm{D}_{2}$ dopamine receptors [12]. Subsequent investigations did not confirm differences between central and peripheral dopamine receptors and suggested using the same nomenclature for both sites [13]. The application of molecular biology to dopamine receptor research has shown that the dopamine receptor family consists of at least five receptor subtypes, which have been included in the family of D1 receptors (renamed D1-like receptors) and of D2 receptors (renamed D2-like receptors) of the former classification [13]. Dopamine D1-like receptors comprise D1 or D1 A and D5 or D1B sites [13]. Dopamine D2-like receptors include two isoforms of the D2 receptor, the so-called D2S (short) and D2L (long) sites, as well as D3 and D4 receptor subtypes [13]. More recently, a new nomenclature defining dopamine receptor subtypes as D1, D2, D3, D4 and D5 was recommended by the Subcommittees of the International Union of Pharmacology on Drug Classification and Receptor Nomenclature (NC-IUPHAR) [14].

Dopamine receptors expressed by cerebral vessels were characterized with biochemical-pharmacological techniques using dopamine-sensitive adenylate cyclase as a marker of dopamine receptors $[15,16]$ and light microscope autoradiography [16]. These investigations did not consider the profile of dopamine receptor subtypes emerging from molecular biology investigations which recognized the 5 previously mentioned dopamine receptor subtypes [13]. The present study was designed to assess the microanatomical localization of dopamine D1-D5 [14] receptor protein immunoreactivity in dog pial arteries by immunohistochemistry.

\section{Materials and methods}

Male mongrel dogs ( $n=5$, age $3.5 \pm 0.4$ years) undergoing necropsy less than $3 \mathrm{~h}$ after death were used. This kind of approach is allowed by internationally accepted principles for care of laboratory animals (European Community Council Directive 86/609, O.J. $\mathrm{n}^{\circ}$ L358, 18 December 1986). After craniotomy, the brain together with the pia-arachnoid membrane was removed and washed in an ice-cold $0.9 \% \mathrm{NaCl}$ solution. The frontal pole was excised and divided into coronal slices of $0.5 \mathrm{~cm}$ each. Slices were fixed for 24 $\mathrm{h}$ in Bouin's fixative, washed, dehydrated, embedded in semi-synthetic paraffin and processed for dopamine receptor immunohistochemistry. In a series of preliminary experiments it was shown that the fixative used gave the best preservation of tissue morphology without affecting immunoreactivity (data not shown).

Serial 8- $\mu \mathrm{m}$ thick sections were mounted on microscope slides and exposed for $12-18 \mathrm{~h}$ at $4^{\circ} \mathrm{C}$ to polyclonal anti-dopamine D1D5 receptor antibodies $[8,9]$ obtained from Calbiochem (San Diego, CA, U.S.A.) or Santa Cruz Biotechnology (Santa Cruz, CA, U.S.A.). The characteristics, working dilution and specificity of these antibodies as assessed in preliminary western blot experiments are summarized in Table 1 . The specificity of immune reaction was evaluated by incubating alternate sections with antibodies pre-adsorbed with blocking peptides used for raising antibodies. Each antiserum was pre-adsorbed with either the corresponding or the non-corresponding receptor blocking peptides. Optimal antibody and blocking peptide concentrations were assessed in a series of preliminary experiments. Control sections were exposed to a

Table 1 Properties of commercial D1-D5 receptors used for western blotting and immunohistochemistry (IH)

\begin{tabular}{|c|c|c|c|c|c|c|}
\hline \multirow[t]{2}{*}{ Receptor } & \multirow{2}{*}{$\begin{array}{c}\text { Epitope } \\
\text { (aminoacids) }\end{array}$} & \multirow[t]{2}{*}{ Species } & \multirow{2}{*}{$\begin{array}{l}\text { Catalog no. } \\
\text { (lot no.) }\end{array}$} & \multicolumn{2}{|c|}{ Working dilutions } & \multirow{2}{*}{$\begin{array}{c}\text { Protein band } \\
\text { (kDa) }\end{array}$} \\
\hline & & & & Western & $\mathrm{IH}$ & \\
\hline D1 & 9-21 Cys-22 & Rabbit & $324390(\mathrm{~B} 20607)^{\mathrm{a}}$ & $1: 1000$ & $1: 5000$ & 50 \\
\hline D2 & Cys-271 272-282 & Rabbit & $324393($ B20061) & $1: 400$ & $1: 5000$ & 48,51 \\
\hline D3 & 2-10 Cys-11 & Rabbit & $324402(\mathrm{~B} 23335)^{\mathrm{a}}$ & $1: 500$ & $1: 2500$ & 49 \\
\hline D4 & 175-186 Cys-187 & Rabbit & $324405(\mathrm{~B} 17850)^{\mathrm{a}}$ & $1: 500$ & $1: 10000$ & $40-42$ \\
\hline D5 & $455-472$ & Goat & $1441^{\mathrm{b}}$ & $1: 200$ & $1: 2500$ & 51 \\
\hline
\end{tabular}

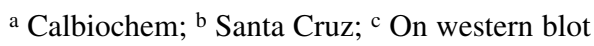


non-immune serum. After incubation with primary antibody, sections were exposed to a secondary biotin-streptavidin conjugated anti-goat or anti-rabbit antibody. The product of immune reaction was then revealed using $0.05 \%$ 3'-3'-diaminobenzidine in $0.1 \%$ $\mathrm{H}_{2} \mathrm{O}_{2}$ as a chromogen. Parallel sections were exposed to a goat tyrosine hydroxylase antiserum (Calbiochem cat. no. 657012) and then processed for immunohistochemistry.

The intensity of dopamine receptor protein immunostaining (brown or dark-brown) developed in the layers (adventitia, media and intima) of different sized dog pial arteries (large, external diameter 200-350 $\mu \mathrm{m}$; medium, external diameter 75-200 $\mu \mathrm{m}$; small, external diameter less than $75 \mu \mathrm{m}$ ) was assessed microdensitometrically. We examined $8-10$ different size pial arteries per animal $(\mathrm{n}=5)$ at a final 250x magnification using a light microscope connected via a TV camera to an IAS 2000 image analyzer (Delta Sistemi, Rome, Italy). The system was calibrated taking as "zero" the background of sections exposed to a non-immune serum. Measurements were then made in five $25-\mu \mathrm{m}^{2}$ areas of each arterial layer per vessel. Microdensitometry data were analyzed statistically by analysis of variance (ANOVA) followed by Duncan's multiple range test.

\section{Results}

Sections of dog pial arteries processed for tyrosine hydroxylase immunohistochemistry had nerve fiber-like structures in the tunica adventitia and in the adventitia-media border (data not shown). Pial arteries exposed to dopamine D1 receptor antibodies developed a faint immune reaction diffused throughout the tunica media and a non-specific background in the tunica adventitia (Fig. 1a, b). Medial immunoreactivity was located within smooth muscle.
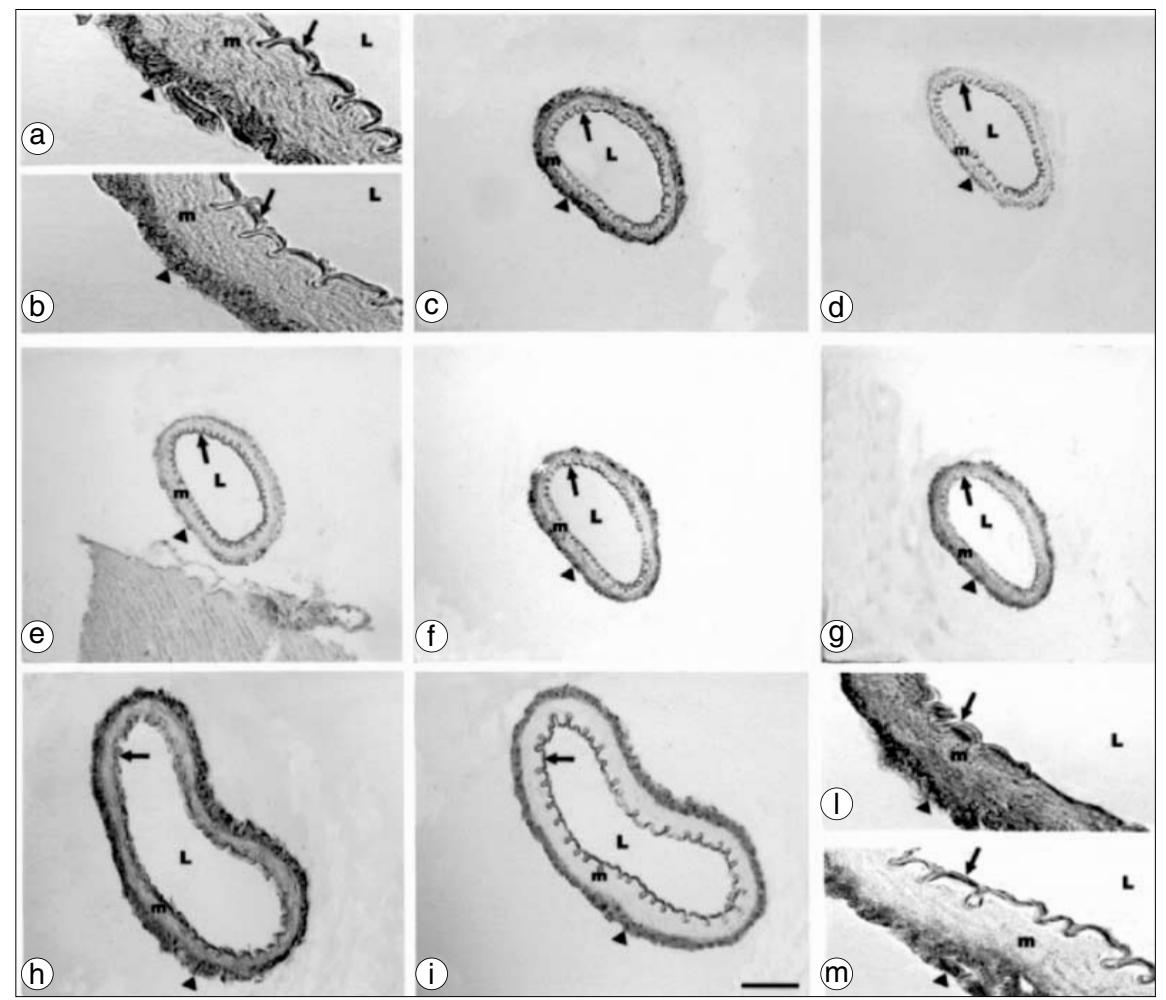

Fig. 1 a, b Sections of large sized dog pial arteries exposed to anti-dopamine D1 receptor protein antibody alone (a) or pre-adsorbed with the corresponding blocking peptide (b). A faint brown immune reaction developed in the tunica media. Immune staining in the tunica adventitia was similar in sections incubated with the antiserum alone (a) or plus blocking peptide (b) indicating that it represents non-specific retention of the antibody by the tissue. c, $\mathbf{d}$ Sections of medium sized dog pial arteries exposed to anti-dopamine D2 receptor antibody alone (c) or preadsorbed with the corresponding receptor blocking peptide (d). A specific immune staining (sensitive to receptor blocking peptide) was localized in the tunica adventitia including the adventitia-media border. e Section of medium sized dog pial artery exposed to anti-dopamine D3 receptor protein antibody. No specific immune staining was observed in various layers of dog pial arteries. $\mathbf{f}, \mathbf{g}$ Sections of medium sized dogs pial arteries exposed to anti-dopamine D4 receptor protein antibody alone (f) or pre-adsorbed with the corresponding receptor blocking peptide (g). Note the development of specific immune staining in the adventitia and the adventitia-media border. $\mathbf{h}, \mathbf{k}$ Sections of large-sized dog pial arteries exposed to anti-dopamine D5 receptor antibody alone (h and $\mathbf{j}$ ) or pre-adsorbed with the corresponding receptor blocking peptide (i and $\mathbf{k})$. i, $\mathbf{k}$ High magnification micrographs of $\mathbf{i}, \mathbf{k}$, respectively. Note the development of a moderate specific immune staining in the tunica media. The immune staining developed in the tunica adventitia represents a non-specific retention of antibody by the tissue since it is insensitive to displacement by receptor blocking peptide. Calibration bars, $35 \mu \mathrm{m}(\mathbf{a}, \mathbf{b}, \mathbf{j}, \mathbf{k}) ; 130 \mu \mathrm{m}(\mathbf{c}-\mathbf{i}) . L$, lumen; $m$, tunica media; arrows, tunica intima; arrowheads, tunica adventitia 
Table 2 Microdensitometric analysis of dopamine receptor immunoreactivity in different sized dog pial arteries. Data are expressed in arbitrary units and are the means \pm SE of microdensitometric measurements. Values were obtained by subtracting the intensity of immune staining of sections incubated with anti-receptor antibodies plus blocking peptides from those obtained with anti-receptor antibodies alone

\begin{tabular}{|c|c|c|c|c|c|c|}
\hline \multirow{2}{*}{$\begin{array}{l}\text { Receptor } \\
\text { subtype }\end{array}$} & \multicolumn{2}{|c|}{ Large $_{\text {arteries }}{ }^{\mathrm{a}}$} & \multicolumn{2}{|c|}{ Medium arteries ${ }^{b}$} & \multicolumn{2}{|c|}{ Small arteries ${ }^{\mathrm{c}}$} \\
\hline & Adventitia & Media & Adventitia & Media & Adventitia & Media \\
\hline D1 & ND & $2.6 \pm 0.1$ & ND & $2.4 \pm 0.3$ & ND & $2.4 \pm 0.1$ \\
\hline D2 & $8.5 \pm 0.4$ & ND & $7.9 \pm 0.5$ & ND & $5.8 \pm 0.3^{*}$ & ND \\
\hline D3 & ND & ND & ND & ND & ND & ND \\
\hline D4 & $3.2 \pm 0.1$ & ND & $2.9 \pm 0.2$ & ND & $2.7 \pm 0.1$ & ND \\
\hline D5 & ND & $7.3 \pm 0.4$ & ND & $6.9 \pm 0.3$ & ND & $10.2 \pm 0.6^{*}$ \\
\hline
\end{tabular}

ND, not detectable

$* p<0.01$ vs. the same layer of large and medium sized arteries.

a 200-350 $\mu \mathrm{m}$ diameter; ${ }^{\text {b }} 75-200 \mu \mathrm{m}$ diameter; ${ }^{\mathrm{c}}<75 \mu \mathrm{m}$ diameter

Microdensitometric analysis of dopamine D1 receptor protein immunoreactivity did not reveal changes in the density of immunoreactivity in the different sized pial arteries (Table 2). Dopamine D2 receptor protein immunoreactivity was located in the adventitia and the adventitia-media border of pial arteries (Fig. 1c, d). The intensity of immune reaction was higher in large and medium than in small arteries (Table 2). No dopamine D3 receptor protein immunoreactivity was observed in dog pial arteries (Fig. 1e), whereas positive immunostaining was seen in islands of Calleja (data not shown). A faint dopamine D4 receptor protein immunoreactivity (Fig. 1f, g) partly reduced by pre-adsorbtion of antibody with dopamine D2 receptor blocking peptide (data not shown) was observed in the adventitia, including the adventitia-media border. The intensity of dopamine D4 receptor immunoreactivity was similar in different sized pial arteries examined (Table 2). A moderate dopamine D5 receptor protein immunoreactivity was seen in the tunica media of different sized pial arteries (Fig. 1h, i) with a higher density in small arteries (Table 2). Dopamine D5 receptor protein immunostaining was located within smooth muscle of pial arteries (Fig. 1j, k).

\section{Discussion}

It has been known for several years that stimulation of specific dopamine receptors causes vasodilatation in several vascular districts including cerebral, coronary, mesenteric and renal vascular beds [16-18]. Vascular effects of dopamine were thought to be mediated through the activation of both post-junctional and prejunctional receptors. Post-junctional receptors, formerly named DA1 or D1 receptors $[12,17]$, are located within arterial smooth muscle and mediate myorelaxation [12, 17]. Prejunctional receptors, formerly termed as DA2 or D2 receptors, are located within sympathetic neuroeffector junctions [12, 18]. Stimulation of these receptors inhibits noradrenaline release from sympathetic neuroeffector junctions with subsequent reduction of vasoconstrictor responses to sympathetic outflow $[12,18]$. As mentioned previously, the application of molecular biology to dopamine receptor research has shown that the picture of central and peripheral dopamine receptors is more complicated than formerly considered, as at least 5 dopamine receptor subtypes have thus far been identified [13, 14]. In spite of the potential interest of drugs interacting with dopamine D1-like and D2-like receptors in cerebrovascular disorders [17, 18], cerebrovascular dopamine receptor subtypes have been characterized only sparsely. One of the reasons for this limited analysis is probably the lack of compounds able to discriminate between dopamine receptor subtypes. The development of antibodies against the five different dopamine receptor subtypes [19-22] may contribute to enlarge our possibilities of characterizing dopamine receptor subtypes, bypassing the limit of selectivity of available dopamine receptor ligands.

In this study, using antibodies against the different dopamine receptors and light microscope immunohistochemistry, the density and localization of dopamine D1-D5 receptors were detailed in different sized dog pial arteries. Dog pial arteries express dopamine D1, D2, D4 and D5 receptor proteins, but not dopamine D3 receptor protein. These findings confirm and extend previous biochemicalpharmacological [23] and autoradiographic studies [16] reporting the existence of dopamine D1-like and D2-like receptors in bovine [23] and [16] cerebral vessels. Analysis 
of dopamine D1 and D5 receptor protein immunoreactivity confirms the hypothesis of a muscular (post-junctional) localization of dopamine D1-like receptors [12, 17]. The demonstration of a stronger D5 than D1 receptor protein immunoreactivity in dog pial arteries is an original contribution of this study. Further work is in progress to evaluate if the D5 receptor is the D1-like subtype more expressed in other vascular beds.

Our immunohistochemical data also support previous data of the existence of dopamine D2-like receptors in pial arteries [16]. Since our investigation was performed on normally innervated pial arteries, we are unable to establish if dopamine D2 and D4 receptor protein immunoreactivity reflects a prejunctional localization. However, the observation that receptor immunoreactivity was located in the same portion of the vascular wall where tyrosine hydroxylase fibers were found suggests that dopamine D2 and D4 receptors have a prejunctional localization. Different from a pre- vious study of our group [16], in this work we did not demonstrate a dopamine D2-like receptor in the endothelium of pial arteries. Species differences or the recognition of a site not corresponding to a D2-like receptor by $\left[{ }^{3} \mathrm{H}\right]$ spiperone are the most probable reasons for these different data.

Dopamine likely represents the second putative protagonist of migraine [24, 25]. Prodromal, accompanying or post-dromal symptoms of migraine may reflect dopaminergic activation and drugs acting directly (receptor agonists and antagonists) or indirectly (flunarizine) on dopamine receptors are effective in prophylaxis or treatment of migraine (reviewed in [26, 27]). However, the possibility that cerebrovascular dopamine receptors might be involved in migraine pathophysiology was not considered yet. The demonstration of both post-junctional (D1 and D5) and prejunctional (D2 and D4) dopamine receptors in cerebral vessels [16-18] may contribute to better clarify the role of dopamine in the pathophysiology of migraine.

\section{References}

1. Bès A, Dupui P, Guell A, Comet B, Géraud G (1984) Dopamine and migraine. In: Mackenzie ET et al (eds) LERS, Vol 2. Raven, New York, pp 41-66

2. Huang Q, Zhou D, Chase K, Gusella JF, Aronin N, DiFiglia M (1992) Immunohistochemical localization of the D1 dopamine receptor in rat brain reveals its axonal transport, pre-and postsynaptic localization, and prevalence in the basal ganglia, limbic system, and thalamic reticular nucleus. Proc Natl Acad Sci USA 89:11988-11992

3. Forster C, Drew GM, Hilditch A, Whalley ET (1983) Dopamine receptor in human basilar arteries. Eur J Pharmacol 87:227-235

4. Toda N (1976) Influence of dopamine and noradrenaline on isolated cerebral arteries of the dog. Br J Pharmacol 48:121-126

5. Sun MH, Ishine T, Lee TJF (1997) Dopamine constricts porcine pial veins. Eur J Pharmacol 334:165-171

6. Edvinsson L, Hardebo JE, McCulloch J, Owman C (1978) Vasomotor response of cerebral blood vessels to dopamine and dopaminergic agonists. Adv Neurol 20:85-96

7. Altura BM, Gebrewold A, Lassoff S (1980) Biphasic responsiveness of rat pial arterioles to dopamine: direct observations on the microcirculation. Br J Pharmacol 69:543-544
8. Edvinsson L, McCulloch J, Sharkey J (1985) Vasomotor responses of cerebral arterioles in situ to putative dopamine receptor agonists. $\mathrm{Br} \mathbf{J}$ Pharmacol 85:403-410

9. Von Essen C (1974) Effects of dopamine on the cerebral blood flow in the dog. Acta Neurol Scand 50:39-46

10. Grasby PM, Friston KJ, Bench CJ, Cowen PJ, Frith CD, Liddle PF, Frackowiak RS, Dolan RJ (1993) The effect of the dopamine agonist, apomorphine, on regional cerebral blood flow in normal volunteers. Psychol Med 23:605-612

11. Duncker DJ, van Meegen JR, Verdouw PD (1997) Cardiovascular actions of the dopamine receptor agonist Z1046 in swine. Cardiovasc Drugs Ther 11:537-545

12. Goldberg LI, Kohli JD (1979) Peripheral pre- and postsynaptic dopamine receptors: are they different from dopamine receptors in the central nervous system? Commun Psychopharmacol 3:447-456

13. Gingrich JA, Caron MG (1993) Recent advances in the molecular biology of dopamine receptors. Annu Rev Neurosci 16:299-321

14. Alexander SPH, Peters JA (1998) Receptor and ion channel nomenclature. Trends Pharmacol Sci Suppl 19:29-30
15. Amenta D, Cavallotti C, Collier WL, De Rossi M, Ricci A, Amenta F (1988) Effect of dopamine on the cyclic adenosine monophosphate generating system in the rabbit internal carotid and middle cerebraly artery. Arch Int Pharmacodyn Ther 291:96-103

16. Amenta F, Ricci, Vega JA (1991) Autoradiographic localization of dopamine receptors in rat cerebral blood vessels. Eur J Pharmacol 192:123-132

17. Clark BJ (1990a) Postjunctional dopamine receptor stimulants. In: Amenta F (ed) Peripheral dopamine pathophysiology. CRC, Boca Raton, pp 253-265

18. Clark BJ (1990) Prejunctional dopamine receptor stimulants. In: Amenta F (ed) Peripheral dopamine pathophysiology. CRC, Boca Raton, pp 267-306

19. Ariano MA, Sibley DR (1994) Dopamine receptor distribution in the rat CNS: elucidation using anti-peptide antisera directed against D1 A and D3 subtypes. Brain Res 649:95-110

20. Bergson C, Mrzljak L, Lidow MS, Goldman-Rakic PS, Levenson R (1995) Characterization of subtypespecific antibodies to the human D5 dopamine receptor: Studies in primate brain and trasfected mammalian cells. Proc Natl Acad Sci USA 92:3468-3472 
21. Defagot MC, Malchiodi EL, Villar MJ, Antonelli MC (1997) Distribution of D4 dopamine receptor in rat brain with sequence-specific antibodies. Mol Brain Res 45:1-12

22. Levey AI, Hersch SM, Rye DB, Sunahara RK, Niznik HB, Kitt CA, Price DL, Maggio R, Brann MR, Ciliax BJ (1993) Localization of D1 and $\mathrm{D} 2$ dopamine receptors in brain with subtype-specific antibodies. Proc Natl Acad Sci USA 90:8861-8865
23. De Keyser J, Ebinger G, De Backer JP, Convents A, Vanderheyden P, Vauquelin G (1988) Subtypes of adrenergic and dopaminergic receptors in bovine cerebral blood vessels.

Neurosci Lett 85:272-276

24. Sicuteri F (1977) Dopamine, the second putative protagonist in headache. Headache 17:129-131

25. Fanciullacci M, Alessandri M, Fusco BM (1990) Migraine. In: Amenta F (ed) Peripheral dopamine pathophysiology. CRC, Boca Raton, pp 219-228
26. Barbanti P, Bronzetti E, Ricci A, Cerbo R, Fabbrini G, Buzzi MG, Amenta F, Lenzi GL (1996) Increased density of dopamine $\mathrm{D}$ receptor in peripheral blood lymphocytes of migraineurs: a marker for migraine? Neurosci Lett 207:73-76

27. Cerbo R, Barbanti P,Buzzi MG, Fabbrini G, Buzzi MG, Brusa L, Roberti C, Zanette EM, Lenzi GL (1997) Dopamine hypersensitivity in migraine: the role of apomorphine test. Clin Neuropharmacol 20:36-41 